Brazilian Journal of Microbiology (2009) 40: 550-562

ISSN 1517-8382

\title{
Aggregatibacter actinomycetemcomitans arcB INFLUENCES HYDROPHOBIC PROPERTIES, BIOFILM FORMATION AND ADHESION TO HYDROXYAPATITE
}

\author{
Longo PL ${ }^{1 *}$; Ota-Tsuzuki $C^{1}$; Nunes ACR ${ }^{1}$; Fernandes $\mathrm{BL}^{1}$; Mintz $\mathrm{K}^{2}$; Fives-Taylor $\mathrm{P}^{2}$; Mayer MPA ${ }^{1}$ \\ ${ }^{1}$ Departamento de Microbiologia, Instituto de Ciências Biomédicas, Universidade de São Paulo, São Paulo, SP, Brasil; \\ ${ }^{2}$ Departament of Molecular Genetics, University of Vermont, Burlington, VT, USA
}

Submitted: September 11, 2008; Returned to authors for corrections: October 27, 2008; Approved: May 03, 2009.

\begin{abstract}
The regulation of gene expression in the oral pathogen Aggregatibacter actinomycetemcomitans is still not fully elucidated. ArcAB is a two-component system which allows facultative anaerobic bacteria to sense various respiratory growth conditions and adapt their gene expression accordingly. This study investigated in A. actinomycetemcomitans the role of $\mathrm{ArcB}$ on the regulation of biofilm formation, adhesion to saliva coated hydroxyapatite (SHA) and the hydrophobic properties of the cell. These phenotypic traits were determined for an $A$. actinomycetemcomitans $\operatorname{arc} \mathrm{B}$ deficient type and a wild type strain. Differences in hydrophobic properties were shown at early and late exponential growth phases under microaerobic incubation and at late exponential phase under anaerobiosis. The $\operatorname{arc} \mathrm{B}$ mutant formed less biofilm than the wild type strain when grown under anaerobic incubation, but displayed higher biofilm formation activity under microaerobic conditions. The adherence to SHA was significantly lower in the mutant when compared with the wild type strain. These results suggest that the transmembrane sensor kinase ArcB, in A. actinomycetemcomitans, senses redox growth conditions and regulates the expression of surface components of the bacterial cell related to biofilm formation and adhesion to saliva coated surfaces.
\end{abstract}

Key words: two component system, gene regulation, adherence, colonization

\section{INTRODUCTION}

The gram-negative facultative anaerobic coccobacillus
Aggregatibacter actinomycetemcomitans is associated with several oral and extra oral infections including localized

*Corresponding Author. Mailing address: Instituto de Ciências Biomédicas - Universidade de São Paulo, Av. Lineu Prestes 1374 São Paulo, SP 05508900 Brazil.; Tel: 55113091734 fax: 5511 30917354.; E-mail: pllongo@usp.br 
aggressive periodontitis (28). The bacterium produces several virulence factors involved in the colonization of the oral cavity, destruction and inhibition of regeneration of the periodontal tissues and evasion of host defense mechanisms $(16,39)$. However, the environmental signals leading to the regulation of most of these factors are still unknown.

Bacteria are able to sense environmental conditions such as secondary metabolites, oxygen concentration, ions and regulatory proteins by a variety of systems including the twocomponent systems signaling in the complex transcriptional regulatory network (3). The Arc (anoxic redox control) twocomponent system allows facultative anaerobic bacteria to sense various respiratory growth conditions and adapt the expression of their genes accordingly. This system consists of the transmembrane sensor kinase $\mathrm{ArcB}$ and the cognate response regulator ArcA (OMPR-like) $(11,23)$.

Under anoxic growth conditions, ArcB autophosphorylates and transphosphorylates ArcA, which then represses or activates the expression of its target operons. Under aerobic conditions, ArcB acts as a phosphatase that catalyzes the dephosphorylation of ArcA-P releasing its transcriptional regulator (24). Upon cessation of signaling, both the cognate response regulator and the sensor kinase undergo dephosphorylation that results in silencing of the system (29).

In Escherichia coli, expression of genes involved in oxygen utilization is down-regulated as oxygen is depleted, and in a reciprocal fashion, expression of genes encoding alternative anaerobic electron transport pathways or genes needed for fermentation are switched on. Many of these metabolic transitions are controlled at the transcriptional level by the two-component ArcAB regulatory system $(13,31,35)$. This system is involved in the up-regulation of tri carboxylic acid cycle genes in strains grown on glucose as the sole carbon source (2) and plays a role in the synthesis of polyhydroxyalkanoic acids (PHAs), which accumulate in the cytoplasm and function as a carbon reservoir (27).

However, many other genes in addition to those involved in redox metabolism are the putative targets of $\mathrm{ArcAB}$ regulation, such as the tra operon for conjugation of resistance plasmid R1 (37), the psi site for Xer-based recombination in plasmid pSC101 (5), the replication site oriC (21), and even operons encoding a putative fimbrial-like protein, Mn-superoxide dismutase and iron uptake system (22). In fact, about $9 \%$ of E. coli open reading frames comprising 55 Arc-regulated operons implicated in energy metabolism, transport, survival, catabolism, and transcriptional regulation are affected either directly or indirectly by ArcA-P (22). It is predicted that 1139 genes in the $E$. coli genome are regulated either directly or indirectly by $\operatorname{ArcA}(34)$.

As a capnophilic microorganism, whose only known habitat is the oral cavity, A. actinomycetemcomitans is not subjected to changes in environmental conditions as $E$. coli, since the latter exhibits a much broader spectrum of habitats, facing anaerobic conditions in the gut but also very oxidized niches as a free-living organism. However, by colonizing oral mucosa surfaces and supra and subgingival dental plaque, $A$. actinomycetemcomitans experiences changes in oxygen tension, as well as in $\mathrm{pH}$, bacterial cells density, concentration of nutrients and metabolic end-products, toxic and signaling molecules. These conditions may be sensed by the organism and may influence gene expression including those related to virulence. Inactivation of $\operatorname{arc} \mathrm{B}$ in $A$. actinomycetemcomitans results in decreased expression of af $u \mathrm{~A}$ and $f t n \mathrm{AB}$ involved in the transport of iron and ferritin (10), and it is likely that this system is also involved in other regulatory pathways.

Since environmental parameters influence bacterial gene expression and the role of the ArcAB two-component system 
is not fully elucidated in A. actinomycetemcomitans, this study aimed to compare the hydrophobic properties and the abilities to form biofilm and to adhere to saliva coated hydroxyapatite of a wild type and an $\operatorname{arcB}$ defective $A$. actinomycetemcomitans mutant under different environmental conditions.

\section{MATERIALS AND METHODS}

\section{Bacterial Strains and Plasmids}

Bacterial strains used in this study are listed in Table 1. A. actinomycetemcomitans was grown in Trypticase Soy broth added with $0.6 \%$ yeast extract (TSB-YE) in a humidified $10 \% \mathrm{CO}_{2}$ incubator at $37^{\circ} \mathrm{C}$. Anaerobic incubation was performed in an anaerobic chamber (Plaslabs- MI/USA) in an atmosphere of $85 \% \mathrm{~N}_{2}, 5 \% \mathrm{H}_{2}$ and $10 \% \mathrm{CO}_{2}$ and $\mathrm{L}$ cysteine (Inlab, São Paulo, Brazil) (0.07\%) was added to TSB-YE. E. coli strains were grown in Luria-Bertani broth at $37^{\mathrm{O}} \mathrm{C}$ with constant aeration. For solid medium, 15g agar per liter was added to the liquid medium. When necessary, antibiotics (kanamycin - $100 \mu \mathrm{g} \mathrm{mL}^{-1}$, spectinomycin- $100 \mu \mathrm{g}$ $\mathrm{mL}^{-1}$ and rifampicin- $100 \mu \mathrm{g} \mathrm{mL}^{-1}$ ) were added.

\section{Construction of a defective $\operatorname{arcB} A$. actinomycetemcomitans}

Analysis of the genome from A. actinomycetemcomitans (www.genome.ou.edu/act.html) revealed a region of homology with $\operatorname{arcB}$ from Haemophilus influenzae and Pasteurella multocida. Several primers were constructed based on this sequence. Primers used in this study are listed in Table 2. Primers arcBforward and arcBreverse were used to amplify the $\operatorname{arcB}$ region using DNA of $A$. actinomycetemcomitans HK1651 as template. The reaction was performed in a Perkin Elmer Thermocycler (CO/USA) with an initial denaturation period at $94^{\circ} \mathrm{C}(5 \mathrm{~min})$, followed by 30 cycles of denaturation at $94^{\circ} \mathrm{C}(30 \mathrm{sec})$, annealing at $55^{\circ} \mathrm{C}(30 \mathrm{sec})$, elongation at $72^{\circ} \mathrm{C}(1.5 \mathrm{~min})$, and a final extension at $72^{\circ} \mathrm{C}(7 \mathrm{~min})$.

The $1861 \mathrm{bp}$ arcB fragment was ligated to pCR2.1-TOPO vector, and cloned in TOPOF10 cells. Transformants were selected in LB with kanamycin. The parcB identity was confirmed by enzymatic restriction with EcoRI, MefI and HindIII and sequencing.

The gene aad 9 encoding spectinomycin resistance was obtained by amplification with specific primers (aad9MfeIforward and aad9MfeIreverse), using pd1269 as template DNA. The PCR was performed with an initial denaturation at $94^{\circ} \mathrm{C}(5 \mathrm{~min}), 30$ cycles of denaturation at $94^{\circ} \mathrm{C}(30 \mathrm{sec})$, annealing at $55^{\circ} \mathrm{C}(30 \mathrm{sec})$, elongation at $72^{\circ} \mathrm{C}$ ( $1 \mathrm{~min})$, and final extension at $72^{\circ} \mathrm{C}(10 \mathrm{~min})$. The aad 9 fragment was ligated to pCR2.1-TOPO vector, cloned in TOPOF10 cells and transformants were selected in LB with kanamycin and spectinomycin. Interruption of the $\operatorname{arc} \mathrm{B}$ gene was obtained by ligating the aad 9 fragment digested with $M f e I$ to parcB digested with the same enzyme. The mixture was electropored in competent E. coli JM109. Transformants were selected in spectinomycin LB agar and plasmid containing $\operatorname{arcB}$ disrupted by $\operatorname{aad} 9$ (parcB/aad9) was identified by enzymatic restriction with EcoRI and $M f e I$.

The EcoRI 2.9kb fragment of parcB/aad9 was ligated with the conjugative plasmid pVT1460 digested with the same enzyme and transformed in E. coli DH5 $\alpha$. The plasmid was extracted and transformed in the conjugative $E$. coli SM10( $\lambda$ pir) competent cells. Transformant cells containing a plasmid with the disrupted $\operatorname{arcB}(\mathrm{pVTarcB} / \mathrm{aad} 9)$ were selected in LB with spectinomycin and plasmid identity was confirmed. 
Table 1. Bacterial strains and plasmids used in this study.

\begin{tabular}{|c|c|c|}
\hline Bacterial strains and plasmids & Description & Reference \\
\hline Aggregatibacter actinomycetemcomitans HK1651 & $\operatorname{arc} \mathrm{B}$ donor & www.genome.ou.edu/act.html \\
\hline \multirow[t]{2}{*}{ A. actinomycetemcomitans $\mathrm{VT} 1169 \mathrm{rif}^{\mathrm{R}} / \mathrm{nal}^{\mathrm{R}}$} & A. actinomycetemcomitans & Mintz; Fives-Taylor $(2000)^{[20]}$ \\
\hline & smooth colony, parent strain & \\
\hline A. actinomycetemcomitans USP71 & $\operatorname{ArcB}$ defective & This study \\
\hline Escherichia coli TOPOF10 & Electrocompetent cells & Invitrogen Life Technologies- Brazil \\
\hline E. coli JM109 & Competent cells. & Promega U.S. (WI/USA) \\
\hline E. coli DH5 $\alpha$ & Competent cells & Promega U.S. (WI/USA) \\
\hline E. coli SM10( $\lambda$ pir $)$ & Conjugative competent cells & Mintz; Fives-Taylor $(2000)^{[20]}$ \\
\hline \multirow[t]{2}{*}{ PCR2.1-TOPO vector } & E. coli clone vector kanamycin & Invitrogen Life Technologies- Brazil \\
\hline & and ampicilin resistant & \\
\hline parcB & $\mathrm{pCR} 2.1-\mathrm{TOPO}+\operatorname{arcB}$ & This study \\
\hline pDL269 & Spectinomycin resistance & Mintz; Fives-Taylor (20) \\
\hline \multirow[t]{2}{*}{ parcB/aad9 } & Plasmid pCR2.1-TOPO $+\operatorname{arcB}$ & This study \\
\hline & disrupted with aad 9 & \\
\hline pVT1460 & Mobilizable plasmid & Mintz et al. (21) \\
\hline \multirow[t]{2}{*}{ pVTarcB/aad9 } & Plasmid pVT1460+ arcB & This study \\
\hline & disrupted with aad9 & \\
\hline
\end{tabular}

Table 2. Primers used for amplification reactions

\begin{tabular}{cr}
\hline Primer & Sequence \\
\hline arcBforward & 5'GTCACGAAATGCTATGAAAAATC3' \\
arcBreverse & 5'ATCAATAACCTGCCAACCAC 3' \\
aad9MfeIforward & 5'CTCCCAATTGATCGATTTTCGTTCGT3' \\
aad9MfeIreverse & 5'CATATGCAAGGGTCAATTGTTTTCT 3' \\
arcBup & 5'ATTGGAACACGCGTTA 3' \\
arcBdown & 5'CATCGGCGTCAACCCTTACTG3' \\
intspec & 5'TCAATGGTTCAGATACGACGACTA3' \\
RT16SrRNA- forward & 5' ACGCTGTAAACGGTGTCG 3' \\
RT16SrRNA- reverse & 5' TTGCATCGAATTAAACCACAT3' \\
RTarcB- forward & 5' GCCAATTTCGCGTTA 3' \\
RTarcB-reverse & 5' TAACGCTGCCCTGTT 3' \\
\hline
\end{tabular}


Longo, P.L. et al.

A mutagenesis system based on that described by Mintz; Fives-Taylor (2000) $)^{(20)}$ was used to generate an $\operatorname{arcB}$ isogenic mutant of $A$. actinomycetemcomitans $\mathrm{VT} 1169 \mathrm{rif}^{\mathrm{R}} / \mathrm{nal}^{\mathrm{R}}$ (SUNY 465 rifampicin and nalidixic acid resistant). $A$. actinomycetemcomitans VT1169, the recipient strain, and $E$. coli SM10( $\lambda$ pir) pVTarcB/aad9, the donor strain, were grown to $\mathrm{OD}_{560 \mathrm{~nm}} \sim 0.5$ and $\sim 0.3$ for donor and recipient strains, respectively.

Cells were suspended in TSB-YE without antibiotic, transferred to the surface of TSB-YE agar, and incubated for conjugation in $10 \% \quad \mathrm{CO}_{2}$ at $37^{\mathrm{O}} \mathrm{C}$ for 5 hours. Transconjugants cells were grown on TSB-YE agar plates containing spectinomycin and rifampicin in $10 \% \mathrm{CO}_{2}$ at $37^{\circ} \mathrm{C}$ for $48 \mathrm{~h}$. Transconjugants were screened by PCR with primer pairs located upstream and downstream $\operatorname{arcB}$ (arcBup and arcBdown) and an internal primer to aad9 gene (intspec) (described in Table 02).

The transconjugant A. actinomycetemcomitans USP71 was selected and disruption of $\operatorname{arcB}$ by insertion of $\operatorname{aad} 9$ at the $M f e I$ site, between the sequence of transmitter domain of $\operatorname{arc} \mathrm{B}$ and receiver and phosphoptranfer domains was confirmed by sequencing using primers arcBup (located $641 \mathrm{pb}$ upstream $\operatorname{arcB}$ ) and arcBdown (located 149pb dowstream $\operatorname{arcB}$ ) exceeding the cloned region in $E$. coli TOPOF10. The sequencing was performed in MegaBACE100 (GE Health Care) with DYEnamic ET Dye Terminatror Kit in Centro de Estudos do Genoma Humano sequencing facility (IB- University of São Paulo/Brazil).

In order to confirm the absence of an intact $\operatorname{arcB}$ transcript in the mutant strain, total RNA from microaerophilic grown cultures $\left(\mathrm{OD}_{500 \mathrm{~nm}} \sim 0.5\right)$ of the wild and the mutant strains were extracted with Trizol LS Reagent (Invitrogen Life Technologies- São Paulo/ Brazil). After DNAse (Invitrogen Life Technologies) treatment, RNA was purified using RNeasy Min Elute Cleanup kit (QIAGENCA/USA) and quantified.

cDNA synthesis was obtained by RT-PCR from total RNA of both strains with random primer by using the Super Script III First Strand Synthesis System (Invitrogen Life Technologies). PCR with primers homologous to $\operatorname{arcB}$ and 16SrRNA (control) (described in Table 02) using cDNA as template were performed, with an initial denaturation step at $94^{\circ} \mathrm{C}(5 \mathrm{~min})$, followed by 30 cycles of denaturation at $94^{\circ} \mathrm{C}$ (30 sec), annealing at $48^{\circ} \mathrm{C}(30 \mathrm{sec})$, elongation at $72^{\circ} \mathrm{C}$ $(45 \mathrm{sec})$ and a final extension at $72^{\circ} \mathrm{C}(7 \mathrm{~min})$.

\section{Bacterial cultures}

Cultures of $A$. actinomycetemcomitans strains VT1169 (wild type) and USP71 ( $\operatorname{arcB} \mathrm{B}^{-}$mutant) grown in anaerobic and microaerophilic conditions at early and late exponential phase were adjusted to an $\mathrm{OD}_{500 \mathrm{~nm}} \sim 0.2$ corresponding to $3 \mathrm{X}$ $10^{8} \mathrm{CFU} \mathrm{mL} \mathrm{mL}^{-1}$. These standardized cultures were used in the following assays.

\section{Adherence to n-hexadecane}

The ability to adhere to n-hexadecane was used to determine the relative surface hydrophobicity as described by Gibbons; Etherden $(1983)^{(14)}$ with some modifications. Bacteria cells grown until early and late exponential phases under microaerophilic and anaerobic conditions were harvested $\left(3,000 \mathrm{x} \mathrm{g} / 20 \mathrm{~min} / 4^{\circ} \mathrm{C}\right)$, washed three times with PUM buffer (16.94g K $\mathrm{HPO}_{4}, 7.26 \mathrm{~g} \mathrm{KH} \mathrm{KH}_{2} \mathrm{PO}_{4}, 1.8 \mathrm{~g}$ urea, $0.2 \mathrm{~g}$ $\mathrm{Mg}_{2} \mathrm{SO}_{4} \cdot 7 \mathrm{H}_{2} \mathrm{O}$ per liter, $\mathrm{pH}$ 7.1) and suspended in the same buffer. The suspensions were adjusted to an $\mathrm{OD}_{550 \mathrm{~nm}}$ of 0.85 $\left(\sim 1 \mathrm{X} 10^{9} \mathrm{CFU} \mathrm{mL}^{-1}\right)$ and transferred to tubes (10 X 100mm).

The bacterial suspensions were added with $400 \mu 1$ of $n$ hexadecane (Sigma- Aldrich, MO/USA) and then equilibrated in a water bath at $30^{\circ} \mathrm{C}$ for 10 minutes. After 
mixing for two 30 seconds periods with 5 seconds in between, the suspensions were allowed to stand for 30 minutes until phase separation. The $\mathrm{OD}_{550 \mathrm{~nm}}$ of the lower aqueous phase was determined and the fraction of adherence was expressed as the percentage of bacteria that remained in the aqueous phase compared with the initial value. All experiments were performed in sextuplicate.

\section{Biofilm Formation Assay}

Biofilm formation was evaluated by the crystal violet staining method (15). Standardized cell cultures of wild type and $\operatorname{arcB}$ deficient mutant were obtained in TSB-YE with antibiotics at initial exponential growth phase. Aliquots of each cell suspension, corresponding to $10^{6}$ and $10^{7} \mathrm{CFU} /$ well were added to wells of a flat-bottomed polystyrene microtiter plate (Corning Inc., NY/USA). Plates were incubated statically under microaerophilic or anaerobic atmospheres at $37^{\circ} \mathrm{C}$ for 14 and 18 hours.

Total growth in the wells was estimated by measuring $\mathrm{OD}_{490 \mathrm{~nm}}$ using a microplate reader (Model 680, Biorad, Tokyo, Japan). Biofilms in the wells were washed with PBS (pH7.3), fixed with methanol for 15 minutes and stained with $0.1 \%$ crystal violet. The dye was eluted with ethanol, and absorbance measured at $600 \mathrm{~nm}$.

Biofilm formation index was the biofilm: planktonic growth ratio between the absorbance value of crystal violet eluted from the biofilm $\left(\mathrm{OD}_{600 \mathrm{~nm}}\right)$ and the absorbance value obtained from the total growth $\left(\mathrm{OD}_{490 \mathrm{~nm}}\right)$. Negative controls contained growth medium without the addition of bacteria suspension. All experiments were performed in sextuplicate.

\section{Adherence to saliva-coated hydroxyapatite (SHA)}

The attachment to SHA was performed as described by Fine et al. (8) with some modifications, in quadruplicate experiments. Whole paraffin-stimulated saliva samples were collected from five periodontally and medically healthy male adults (27-35 years old). Pooled saliva was clarified by centrifugation $\left(10,000 \mathrm{xg} / 30 \mathrm{~min} / 4^{\circ} \mathrm{C}\right)$ and the supernatant was heated to $60^{\circ} \mathrm{C}$ for 30 minutes to inactivate degradative enzymes. Salivary collection was aliquoted and frozen ($20^{\circ} \mathrm{C}$ ) until use.

Sterile 50mg spheroidal hydroxyapatite beads (BDH Chemicals, Poole/England) were washed and equilibrated overnight at $37^{\circ} \mathrm{C}$ in buffered $\mathrm{KCl}(0.05 \mathrm{mM} \mathrm{KCl}, 1 \mathrm{mM}$ potassium phosphate, pH6.0, $1 \mathrm{mM} \mathrm{CaCl}_{2}, 0.1 \mathrm{mM} \mathrm{MgCl}_{2}$ ). Clarified saliva $(800 \mu \mathrm{l})$ was added to the beads and incubated for 2 hours at $37^{\circ} \mathrm{C}$ under slow rotation. Tubes were centrifuged $(12,000 \mathrm{x} \mathrm{g} / 5 \mathrm{~min})$ and the beads were washed three times with buffered $\mathrm{KCl}$.

A. actinomycetemcomitans VT1169 and the isogenic $\operatorname{arc} \mathrm{B}^{-}$mutant were grown until early exponential phase in microaerophilic atmosphere and cells concentration adjusted

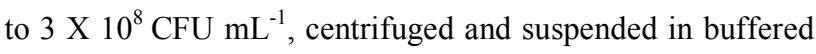
$\mathrm{KCl}$. Bacterial suspensions $(1 \mathrm{ml})$ were added to SHA beads and the mixture was incubated for 2 hours at $37^{\circ} \mathrm{C}$ with slow rotation. After incubation, the complex beads/bacteria was washed three times with buffered $\mathrm{KCl}$. Cells attached to the SHA were removed by 30 seconds sonication at low power pulse (Branson Ultrasonic Cleaner, CT/USA). After sonication, the beads were allowed to settle to the bottom of the tube for 2 minutes. Aliquots of supernatant of non sonicated and sonicated mixtures were serially diluted and plated in TS-YE agar with antibiotics for CFU estimation.

The number of unbound cells was estimated as the number of CFU in the supernatant of the non-sonicated tubes. Bound cells were calculated by subtracting the number of cells in the supernatant after sonication from the number of cells in the non sonicated mixtures. 


\section{Statistical Analysis}

Student t-test was used to compare the ratio between absorbance values of biofilm and planktonic growth, and the number of cells adherent to SHA beads of strains $A$. actinomycetemcomitans VT1169 (wild type) and the isogenic $\operatorname{arcB}$ deficient mutant (USP71). Two-way analysis of variance with posterior multiple comparisons by Tukey was used to detect differences in mean percent values of cells remaining in the aqueous phase in the hydrophobicity assay. The significance level used was $\mathrm{p}<0.05$.

\section{RESULTS}

Construction and characterization of an $A$. actinomycetemcomitans arcB deficient mutant

A recombinant strain originated from $A$. actinomycetemcomitans VT1169 was obtained by disruption of $\operatorname{arc} \mathrm{B}$ with a spectinomycin resistance cassette. The mutant was screened by amplification of the $\operatorname{arc\mathrm {B}}$ region, and one mutant (USP71) was selected (Figure 01). Sequencing of the $\operatorname{arc\mathrm {B}}$ region of strain USP71 revealed that $\operatorname{arc\mathrm {B}}$ was disrupted by aad 9 , in the region encoding the histidine kinase signaling and ATP binding site in a single recombination step. Dowstream the $\operatorname{arc\mathrm {B}}$ region there is a ribosomal binding site and an open reading frame site indicating that other genes were not affected by the spectinomycin insertion.

Disruption of gene coding for ArcB in the mutant strain was confirmed by RT-PCR. The $\operatorname{arcB}$ transcript was absent in the isogenic mutant strain but present in the wild type strain. A transcript of the predicted size for the control gene (16SrRNA) was present in both strains (Fig. 1).

\section{Adherence to n-hexadecane}

The adherence to $n$-hexadecane, representing cell hydrophobicity, was expressed as the percentage of bacteria that remained in the aqueous phase after the treatment compared with the initial value. As shown in Figure 2, the wild type cells were more hydrophobic than the $\operatorname{arc} \mathrm{B}^{-}$mutant in the late exponential growth phase under microaerophilic and anaerobic conditions, and these differences were statistically significant. In addition, a small but significant difference in hydrophobic properties between both strains was shown in early exponential phase after microaerophilic incubation, but not after growth under anaerobic conditions.
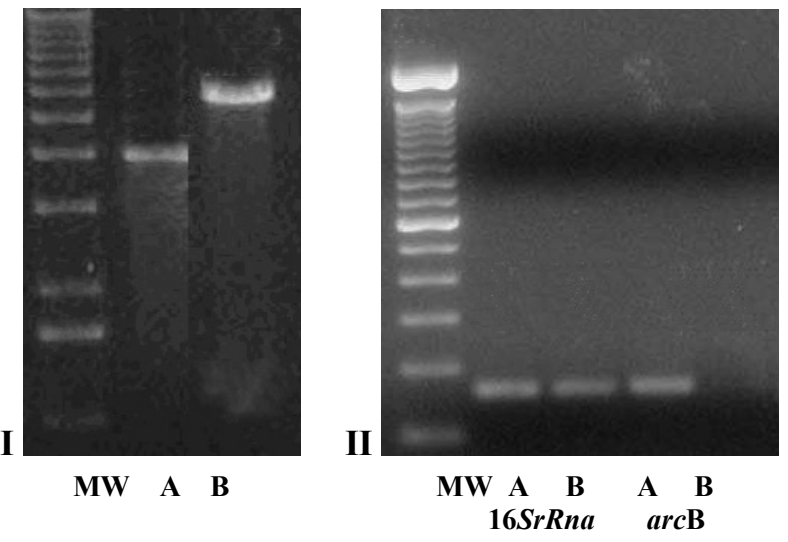

Figure 1. I: $1 \%$ agarose gel after electrophoresis of PCR products using template DNA of wild type (VT1169) and $\operatorname{arc} \mathrm{B}^{-}$mutant (USP71) A. actinomycetemcomitans strains. MW: $1 \mathrm{~Kb}$ plus DNA ladder (Invitrogen Life TechnologiesSão Paulo- Brazil) and amplification with primers upstream and downstream of $\operatorname{arcB}(\operatorname{arcBup}$ e $\operatorname{arcBdown})$. A: VT1169 ( $\sim 3.5 \mathrm{~Kb}$ amplicon) and B: USP71 (5Kb amplicon). II: $2 \%$ agarose gel after electrophoresis with MW: molecular weight 100bp molecular weight marker (Invitrogen Life Technologies, São Paulo- Brazil) and RT-PCR products with primers to $16 \operatorname{SrRNA}(160 \mathrm{bp})$ and $\operatorname{arcB}(163 \mathrm{bp})$ genes using as template cDNA from A: wild strain (VT1169) and B: mutant strain (USP71). 


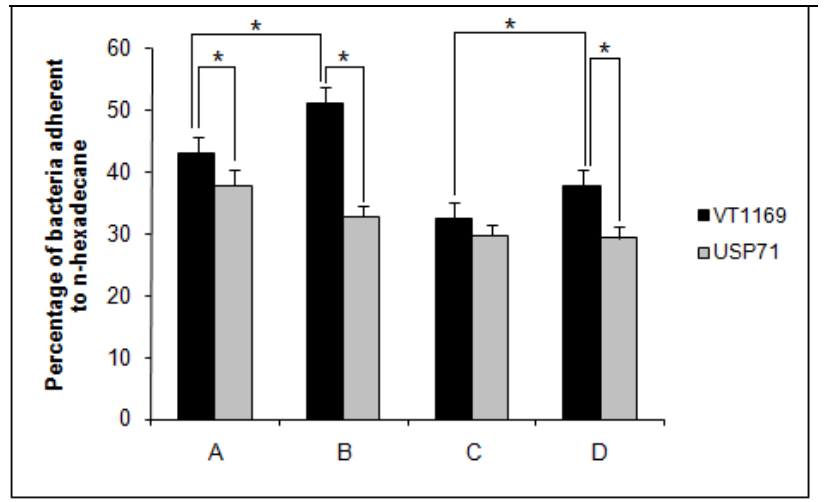

Figure 2. Percentage of bacteria adherent to n-hexadecane of A. actinomycetemcomitans VT1169 (wild type) and USP71( $\operatorname{arcB}^{-}$mutant) grown under microaerophilic incubation until early (A) and late (B) exponential phase, and grown under anaerobic incubation until early (C) and late (D) exponential phase (average and standard deviation of sextuplicate assays). (*statistical significant differences Student t-test $-\mathrm{p}<0.05$ ).

Multiple comparison analysis (Tukey) showed that the wild type cells grown until the late exponential phase were more hydrophobic than those cells grown in early exponential phase either under anaerobic or microaerophilic atmospheres. The difference in hydrophobicity between early and late exponential phases was not observed with the mutant strain. The hydrophobic properties of the $\operatorname{arc\mathrm {B}^{-}}$ mutant remained constant throughout the different growth phases under anaerobic and microaerophilic conditions. Interestingly, the cells grown under anaerobic conditions were more hydrophilic than those bacteria grown in the presence of $10 \%$ carbon dioxide, especially at late exponential phase.

\section{Biofilm formation}

Under microaerophilic growth conditions, there was no difference in the amount of biofilm formed between the wild type and the mutant strains using an inoculum of $10^{6} \mathrm{CFU} /$ well after 14 and 18 hours of incubation (Fig. 3) However, unlike the wild type strain where there was greater biofilm formation when grown under anaerobic conditions as compared with microaerophilic growth conditions, the mutant strain formed less biofilm under anaerobic growth.

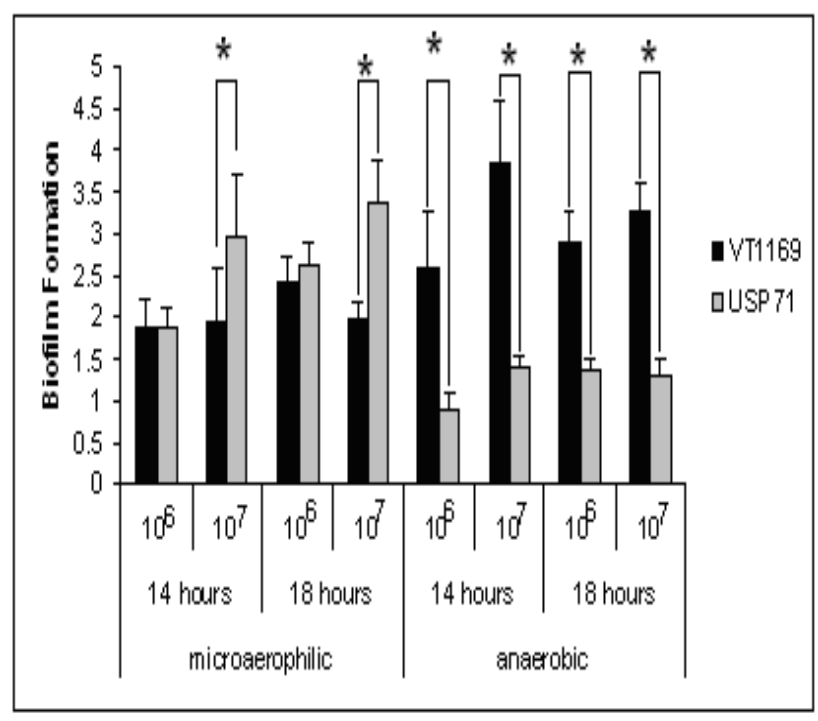

Figure 3. Biofilm formation of strains VT1169 and USP71 grown under microaerophilic and anaerobic conditions, in 14 and 18 hours of incubation and with different initial inoculum $\left(10^{6}\right.$ and $\left.10^{7} \mathrm{CFU} / \mathrm{ml}\right)$ (mean values). (*statistical significant differences - Student t-test $-\mathrm{p}<0.05)$.

When a larger inoculum was used to establish the biofilm $\left(10^{7} \mathrm{CFU} / \mathrm{well}\right)$, significant differences in biofilm formation between the two strains was 
observed under microaerophilic incubation. The $\operatorname{arcB}$ deficient mutant exhibited a higher biofilm formation index in microaerophilic incubation for 14 and 18 hours. This is in contrast to wild type strain which showed a higher biofilm formation under anaerobic incubation for both time periods and inoculum than the $\operatorname{arc} \mathrm{B}^{-}$mutant (Fig. 3).

\section{Adherence to saliva-coated hydroxyapatite (SHA)}

The ability to adhere to saliva-coated hydroxyapatite was compared between strains grown until early exponential phase in microaerophilic atmosphere in a quadruplicate assay. The $\operatorname{arc} \mathrm{B}$ deficient mutant showed a significant $(\mathrm{p}<0.001)$ lower ability (average $3.0+-0.16)$ to adhere to SHA when compared to the wild type (average $20.06+-$ 2.99).

\section{DISCUSSION}

Bacteria involved in periodontal diseases live in a highly complex and continuously changing microenvironment to which they must rapidly adapt in order to survive (9). Biofilm growth promotes a gradual decrease in the oxygen concentration within time, favoring anaerobic bacteria (4). For an opportunistic periodontopathogen such as $A$. actinomycetemcomitans, the presence of systems responding to alteration in oxygen content may be particularly important, due to differences in redox conditions found between oral habitats such as the mucosa, the supragingival biofilm and the periodontal pocket. These variations are not only spatial but also temporal and it is assumed that the switch from being a commensal organism to a pathogen depends on cues obtained from the host, or from other members of the oral microbiota, or a combination of both.

It has been previously shown that $A$. actinomycetemcomitans cells grown in an anaerobic atmosphere differed from those seen in aerobic cultures, since the presence of oxygen $/ \mathrm{CO}_{2}$ was associated with the upregulation of five surface associated proteins and a decrease in the levels of a $23 \mathrm{kDa}$ protein (9).

In the present study, the $\operatorname{arcB}$ defective mutant and the wild type strain grew at a similar rate both under microaerophilic and anaerobic atmospheres in planktonic cultures in a rich medium (data not shown). A previous report had also shown that inactivation of $\operatorname{arc} \mathrm{B}$ had little effect on the aerobic growth of $A$. actinomycetemcomitans under ironreplete conditions, but the isogenic strain grew poorly under anaerobic condition. On the other hand, in aerobic condition, the mutant grew poorly under iron-limiting conditions, indicating that the system $\mathrm{Arc} A \mathrm{~B}$ is involved in the iron metabolism (10).

Phenotypic changes associated with oxygen concentration were shown in the wild type strain. Cells grown under aerobic cultures (with $\mathrm{CO}_{2}$ ) were more hydrophobic than those grown under anaerobiosis. In addition, cell hydrophobicity increased from early exponential to late exponential growth phases in the wild type cultures, indicating regulation of cell associated proteins of $A$. actinomycetemcomitans according to growth phase and oxygen concentration. Other studies have also reported that hydrophobic properties are influenced by several experimental variables including culture medium composition and age of the culture $(14,19)$.

These changes in the cell surface according to incubation atmosphere and growth phase were absent in the $\operatorname{arc} \mathrm{B}$ deficient strain indicating that this two-component system is involved in the regulation of expression of cell surface proteins in A. actinomycetemcomitans.

Hydrophobic properties have been associated with bacterial interaction with host tissues $(14,19)$. In biological systems, hydrophobicity depends on the amount of hydrophobic or 
nonpolar aminoacids in the surface proteins, determined by the number of hydrogen-carbon bonds that the molecule contains (20). Thus, the more hydrophilic phenotype observed in the $\operatorname{arc} \mathrm{B}$ deficient mutant reflected in the ability of the mutant to adhere to saliva coated hydroxyapatite and to accumulate as a biofilm.

The $\operatorname{arc} \mathrm{B}$ deficient mutant exhibited a reduced ability to adhere to SHA when compared to the wild type. In addition, this strain formed less biofilm than the wild type under anaerobic incubation, but showed higher biofilm formation ability under microaerophilic incubation. Interestingly, the wild type exhibited an opposite behavior, forming more biofilm under anaerobic incubation than under microaerophilic conditions. Differences in biofilm formation and hydrophobicity according to oxygen concentration at the same growth phase points out that $\mathrm{ArcB}$ is functional in $A$ actinomycetemcomitans and able to sense oxygen concentrations.

The Arc $A B$ system is considered a microaerobic redox regulator (1). However, the differences between wild type and $\operatorname{arc} \mathrm{B}$ deficient mutant strains were observed in $A$. actinomycetemcomitans not only according to the atmosphere of incubation but also regarding to growth phases, indicating that the differential expression of genes induced by ArcAB system may be signaled by other secondary metabolites, as shown for other ArcAB regulated systems.

In $E$. coli certain fermentation intermediates like acetate and pyruvate accelerate the autophosphorylation activity of ArcB (12), and D-lactate acts as a significant effector that amplifies ArcB kinase activity (33). In addition, ArcB not only phosphorylates ArcA, but also the $\sigma^{\mathrm{S}}$ proteolytic targeting factor RssB, suggesting that the redox state of quinones, which controls autophosphorylation of ArcB, not only monitors oxygen but also energy supply (25). Thus, ArcA, ArcB and RssB can constitute a branched "three- component system", which coordinates rpoS transcription and $\sigma^{\mathrm{S}}$ proteolysis and thereby maintains low $\sigma^{\mathrm{S}}$ levels in rapidly growing cells (25).

Our data have also indicated that the ability to form biofilm was influenced by the density of the initial inoculum. No differences between the $\operatorname{arcB}$ deficient mutant and the wild strain were demonstrated in biofilm formed under microaerophilic conditions when $10^{6} \mathrm{CFU} / \mathrm{ml}$ starting cultures were used. However, when a denser inoculum was used $\left(10^{7} \mathrm{CFU} / \mathrm{ml}\right)$, an increased ability to form biofilm was observed for the $\operatorname{arc} \mathrm{B}$ defective strain, when compared to the wild type. On the other hand, under anaerobic conditions, the wild strain formed more biofilm than the $\operatorname{arcB}$ defective mutant using either $10^{6}$ or $10^{7} \mathrm{CFU} / \mathrm{ml}$ starting cultures.

Biofilm formation requires a variety of genes including quorum-sensing systems, environmental sensing twocomponent systems, general stress response pathways, and those encoding surface adhesins involved in cell-cell or cellto-surface interactions $(6,7,36,38)$.

Initial adhesion to surfaces by $A$. actinomycetemcomitans is dependent on the fimbria encoded by the tad locus but the smooth strains used in this study do not express the tad fimbriae that are found in clinical isolates (30). Thus, the biofilm studied here was fimbria independent and other components such as PGA (poly-N-acetyl-glucosamine) may play a role in the aggregation of cells and in the detachment of cells from the colony $(15,17,18)$.

These differential phenotypes between wild type and the $\operatorname{arc} \mathrm{B}$ deficient mutant are indicative of differences in the transcription of some genes or operons related to cell surface components and biofilm formation directly or indirectly induced by the ArcAB system.

Fong et al. (10) observed that LuxS-dependent response in A. actinomycetemcomitans may require the ArcB sensor kinase suggesting that it may contribute to the signal 
transduction cascade that directs the response of $A$. actinomycetemcomitans to AI-2. This inductor itself is required for adhesion to a saliva coated surface and biofilm growth by $A$. actinomycetemcomitans and it was suggested that redundant mechanisms may exist in this microorganism for interacting with AI-2 (36).

The ability to form biofilms by either rough or smooth phenotypes of A. actinomycetemcomitans on a plastic surface is influenced by the presence of haemin (32), thus the interference in iron acquisition by $\mathrm{ArcB}$ (10) may have induced the lower biofilm formation phenotype in the $\operatorname{arcB}$ mutant strain. However, it should be pointed out that the experimental conditions employed in this study were not iron chelating since an iron rich medium (TSB-YE) was used.

Differences shown here between wild type and the $\operatorname{arcB}$ defective mutant clearly indicated that in $A$. actinomycetemcomitans, the transmembrane sensor kinase $\mathrm{ArcB}$ is able to sense oxygen concentration in the environment, and the low redox turns on the ArcAB system, influencing gene expression. They also suggested that ArcB may be involved in sensing other environmental signals as shown for differences in growth culture phases and variation in cells density in the biofilm assay.

In addition, we have shown that ArcB is involved in the regulation of expression of bacterial surface components related to hydrophobic properties, biofilm formation and adhesion to saliva coated surfaces, as demonstrated by differences in these properties between the wild type and the $\operatorname{arc} \mathrm{B}$ deficient mutant. Thus, these data indicated that $A$. actinomycetemcomitans may exhibit different phenotypes according to its microenvironment in the oral cavity.

\section{CONCLUSION}

The sensor kinase ArcB, in $A$. actinomycetemcomitans, senses environmental redox conditions and regulates the expression of surface components related to biofilm formation and interaction with salivary proteins adsorbed to surfaces.

\section{AKNOWLEDGMENTS}

This study was supported by FAPESP grants 03/01192-9 and $03 / 08598-0$

\section{RESUMO}

arcB em Aggregatibacter actinomycetmcomitans

\section{influencia propriedades hidrofóbicas, formação de} biofilme e aderência a hidroxiapatita

A regulação da expressão gênica do patógeno oral Aggregatibacter actinomycetemcomitans não está completamente descrita. O sistema de dois componentes ArcAB permite que bactérias anaeróbias facultativas percebam diferenças nas condições respiratórias durante sua multiplicação e adaptem a expressão de genes à estas condições. Este estudo investigou em $A$. actinomycetemcomitans o papel de ArcB na regulação da formação de biofilme, aderência à hidroxiapatita recoberta por saliva (SHA) e nas propriedades hidrofóbicas celulares. Estas características fenotípicas foram determinadas para uma linhagem de A. actinomycetemcomitans deficiente em $\operatorname{arcB}$ e para uma linhagem selvagem. Foram observadas diferenças nas propriedades hidrofóbicas entre as linhagens quando estas foram cultivadas em ambiente microaerófilo até início e final de fase exponencial e quando foram cultivadas em ambiente 


\section{A. actinomycetemcomitans arc $\mathrm{B}$}

anaeróbio até final de fase exponencial. A linhagem $\operatorname{arc} \mathrm{B}$ mutante formou menos biofilme do que a linhagem selvagem quando estas foram cultivadas sob incubação anaeróbica, porém, apresentou maior formação de biofilme quando a incubação foi realizada em condições de microaerofilia. A aderência à SHA apresentada pela linhagem mutante foi significantemente menor do que a observada pela linhagem selvagem. Estes estudos sugerem que a quinase sensora ArcB, em A. actinomycetemcomitans, percebe as condições redox de multiplicação e regula a expressão de componentes de superfície bacterianos relacionados à formação de biofilme e adesão a superfícies recobertas com saliva.

Palavras- chave: sistema de dois componentes, regulação gênica, aderência, colonização

\section{REFERENCES}

1. Alexeeva, S.; Hellingwerf, K.J.; Mattos, M.J.T. (2003). Requirement of ArcA for redox regulation in Escherichia coli under microaerobic but not anaerobic or aerobic conditions. J. Bacteriol. 185 (1), 204- 209.

2. Báez-Viveros, J.L.; Flores, N.; Suarez, K.; Castillo-Espana, P.; Bolivar, F.; Gosset, G. (2007). Metabolic transcription analysis of engineered Escherichia coli strains that overproduce L-phenylalanine. Microb. Cell Fact. 6, 30- 50.

3. Bijlsma, J.J.E.; Groisman, E.A. (2003). Making informed decisions: regulatory interactions between two-component systems. TRENDS in Microbiol. 11(8), 359- 366.

4. Bradshaw, D.J.; Marsh, P.D.; Allison, C. Schilling, K.M. (1996). Effect of oxygen, inoculum composition and flow rate on development of mixed-culture oral biofilms. Microbiol. 142 (3), 623- 629.

5. Colloms, S.D.; Alén, C.; Sherratt, D.J. (1998) The ArcA/ArcB twocomponent regulatory system of Escherichia coli is essential for Xer site-specific recombination at psi. Mol. Microbiol. 28 (3), 521- 530.

6. Davey, M.E.; Costerton, J.W. (2006). Molecular genetics analyses of biofilm formation in oral isolates. Periodontol 2000. 42 (1), 13-26.
7. Davies, D.G.; Parsek, M.R.; Pearson, J.P.; Iglewski, B.H.; Costerton, J.W.; Greenberg, E.P. (1998). The involvement of cell-to-cell signals in the development of a bacterial biofilm. Science. 280 (5361), 295- 298.

8. Fine, D.H.; Furgang, D.; Kaplan, J.; Charlesworth, J.; Figurski, D.H. (1999). Tenacious adhesion of Actinobacillus actinomycetemcomitans strain CU1000 to salivary coated-hydroxyapatite. Arch. Oral. Biol. 44 (12), 1063- 1076 .

9. Fletcher, J.M.; Nair, S.P.; Ward, J.M.; Henderson, B.; Wilson, M. (2001). Analysis of the effect of changing environmental conditions on the expression patterns of exported surface-associated proteins of the oral pathogen Actinobacillus actinomycetemcomitans. Microb. Pathog. $30(6), 359-368$.

10. Fong, K.P.; Gao, L.; Demuth, D.R. (2003) $\operatorname{luxS}$ and $\operatorname{arcB}$ control aerobic growth of Actinobacillus actinomycetemcomitans under iron limitation. Infect. Immun. 71 (1), 298-308.

11. Georgellis, D.; Kwon, O.; DeWulf, P.; Lin, E.C. (1998). Signal decay through a reverse phosphorelay in the Arc two-component signal transduction system. J. Biol. Chem. 273 (49), 32864- 32869.

12. Georgellis, D.; Kwon, O.; Lin, E.C. (1999). Amplification of signaling activity of the arc two-component system of Escherichia coli by anaerobic metabolites- an in vitro study with different protein modules. J. Biol. Chem. 274 (50), 35950- 35944.

13. Georgellis, D.; Kwon, O.; Lin, E.C.; Wong, S.M.; Akerley, B.J. (2001). Redox signal transduction by the ArcB sensor kinase of Haemophilus influenzae lacking the PAS domain. J. Bacteriol. 183 (24), 7206- 7212.

14. Gibbons, R.J.; Etherden, I. (1983). Comparative hydrophobicities of oral bacteria and their adherence to salivary pellicles. Infect. Immun. 41 (3), 1190- 1196 .

15. Haase, E.M.; Bonstein, T.; Palmer, R.J.Jr.; Scannapieco, F.A. (2006). Environmental influences on Actinobacillus actinomycetemcomitans biofilm formation. Arch. Oral. Biol. 51 (4), 299-314.

16. Henderson, B.; Nair, S.P.; Ward, J.M.; Wilson, M. (2003). Molecular pathogenicity of the oral opportunistic pathogen Actinobacillus actinomycetemcomitans. Annu. Rev. Microbiol. 57, 29-55.

17. Izano, E.A.; Wang, H.; Ragunath, C.; Ramasubbu, N.; Kaplan, J.B. (2007). Detachment and killing of Aggregatibacter actinomycetemcomitans biofilms by dispersin B and SDS. J. Dent. Res. $86(7), 618-622$.

18. Kaplan, J.B.; Velliyagounder, K.; Ragunath, C.; Rhode, H.; Mack, D.; Knobloch, J.K.; Ramasubbu, N. (2004). Genes involved in the synthesis and degradation of matrix polysaccharide in Actinobacillus actinomycetemcomitans and Actinobacillus pleuropneumoniae biofilms. J. Bacteriol. 186 (24), 8213-8220. 
19. Kozlovsky, A.; Metzger, Z.; Eli, I. (1987). Cell surface hydrophobicity of Actinobacillus actinomycetemcomitans Y4. J. Clin. Periodontol. 14 (6), 370- 372 .

20. Kyte, J. (2003). The basis of the hydrophobic effect. Biophys. Chem. 100 (1-3), 193- 203.

21. Lee, Y.S.; Han, J.S.; Jeon, Y.; Hwang, D.S. (2001). The arc twocomponent signal transduction system inhibits in vitro Escherichia coli chromosomal initiation. J. Biol. Chem. 276 (13), 9917- 9923.

22. Liu, X.; Wulf, P.D. (2004). Probing the ArcA-P modulon of Escherichia coli by whole genome transcriptional analysis and sequence recognition profile. J. Biol. Chem. 279 (13), 12588- 12597.

23. Lynch, A.S.; Lin, E.C. (1996). Transcriptional control mediated by the ArcA two component response regulator protein of Escherichia coli: characterization of DNA binding at target promoters. J. Bacteriol. 178 (21), 6238- 6249 .

24. Malpica, R.; Sandoval, G.R.; Rodriguez, C.; Franco, B.; Georgellis, D. (2006). Signaling by the arc two-component system provides a link between the redox state of the quinone pool and gene expression . Antioxid. Redox Signal. 8 (5-6), 781- 795.

25. Mika, F.; Hengge, R. (2005). A two-component phosphotransfer network involving ArcB, ArcA, and RssB coordinates synthesis and proteolysis of $\sigma^{\mathrm{S}}$ (RpoS) in E. coli. Genes Devel. 19 (22), 2770- 2781.

26. Mintz, K.P.; Fives-Taylor, P.M. (2000). impA, a gene coding for an inner membrane protein, influences colonial morphology of Actinobacillus actinomycetemcomitans. Infect. Immun. 68 (12), 65806586.

27. Nikel, P.I.; Pettinari, M.J.; Galvagno, M.A.; Méndez, B.S. (2006). Poly (3-hydroxybutyrate) synthesis by recombinant Escherichia coli arcA mutants in microaerobiosis. App. Env. Microbiol. 72 (4), 2614- 2620.

28. Norskov-Lauritsen, N.; Kilian, M. (2006). Reclassification of Actinobacillus actinomycetemcomitans, Haemophilus aphrophilus, Haemophilus paraphrophilus and Haemophilus segnis as Aggregatibacter actinomycetemcomitans gen. nov., Aggregatibacter aphrophilus comb. nov. and Aggregatibacter segnis comb. nov., and emended description of Aggregatibacter aphrophilus to include $\mathrm{V}$ factor-dependent and V factor- independent isolates. Int. J. Syst. Evol. Microbiol. 56 (9), 2135-2146.

29. Peña-Sandoval, G.R.; Kwon, O.; Georgellis, D. (2005). Requirement of the receiver and phosphotransfer domains of ArcB for efficient dephosphorylation of phosphorylated ArcA in vivo. J. Bacteriol. 187 (9), 3267- 3272.

30. Perez, B.A.; Planet, B.J.; Kachlany, S.C.; Tomich, M.; Fine, D.H.; Figursky, D.H. (2006). Genetic analysis of the requirement for $f l p-2$, tad $\mathrm{V}$, and $r c p \mathrm{~B}$ in Actinobacillus actinomycetemcomitans biofilm formation. J. Bacteriol. 188 (17), 6361- 6375.

31. Perrenoud, A.; Sauer, U. (2005). Impact of global transcriptional regulation by ArcA, ArcB, Cra, Crp, Cya, Fnr and Mlc on glucose catabolism in Escherichia coli. J. Bacteriol. 187 (9), 3171-3179.

32. Rhodes, E.R.; Shoemaker, C.J.; Menke, S.M.; Edelmann, R.E.; Actis, L.A. (2007). Evaluation of different iron sources and their influence in biofilm formation by the dental pathogen Actinobacillus actinomycetemcomitans. J. Med. Microbiol. 56 (1), 119- 128.

33. Rodriguez, C.; Kwon, O.; Georgellis, D. (2004). Effect of D-lactate on the physiological activity of the ArcB sensor kinase in Escherichia coli. J. Bacteriol. 186 (7), 2085- 2090.

34. Salmon, K.A.; Hung, S.; Steffen, N.R.; Krupp, R.; Baldi, P.; Hatfield, G.W.; Gunsalus, R.P. (2005). Global gene expression profiling in Eescherichia coli K12. J. Biol. Chem. 280 (15), 15084- 15096.

35. Shalel-Levanon, S.; San, K.Y.; Bennette, G.N. (2005). Effect of ArcA and FNR on the expression of genes related to the oxygen regulation and the glycolysis pathway in Escherichia coli under microaerobic growth conditions. Biotech. Bioengin. 92 (2), 147-149.

36. Shao, H.; Lamont, R.J.; Demuth, D.R. (2007). Autoinducer 2 is required of biofilm growth of Aggregatibacter (Actinobacillus) actinomycetemcomitans. Infect. Immun. 75 (9), 4211- 4218.

37. Strohmaier, H.; Noiges, R.; Kotschan, S.; Sawers, G.; Hogenauer, G.; Zechner, E.L.; Koraimann, G. (1998). Signal transduction and bacterial conjugation: characterization of the role of ArcA in regulating conjugative transfer of the resistance plasmid R1. J. Mol. Biol. 277 (2), 309- 316 .

38. Yarwood, J.M.; Bartels, D.J.; Volper, E.M.; Grinberg, E.P. (2004). Quorum sensing in Staphylococcus aureus biofilms. J. Bacteriol. 186 (6), 1838- 1850.

39. Yue, G.; Kaplan, J.B.; Furgang, D.; Mansfield, K.G.; Fine, D.H. (2007). A second Aggregatibacter actinomycetemcomitans autotransporter adhesion exhibits specificity for buccal epithelial cells in humans and old world Primates. Infect. Immun. 75 (9), 4440- 4448. 